\title{
Transnationalizing Families:
}

Canadian Immigration Policy and the Spatial Fragmentation of Care-giving among Latin American Newcomers

Judith K. Bernhard

Ryerson University

\section{Patricia Landolt}

University of Toronto

\section{Luin Goldring}

York University

Bernhard, J. K., Landolt, P., \& Goldring, L. (2009), Transnationalizing families: Canadian immigration policy and the spatial fragmentation of care-giving among Latin American newcomers. International Migration, 47(2), 3-31.

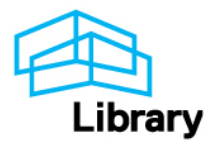


Transnationalizing Families:

Canadian Immigration Policy and the Spatial Fragmentation of Care-giving among Latin American Newcomers ${ }^{1}$

Judith K. Bernhard, Ryerson University

Patricia Landolt, University of Toronto

Luin Goldring, York University

Manuscript accepted in International Migration 


\begin{abstract}
Complex factors associated with migration and immigration policies contribute to the dispersion of families across space. We draw on interviews with 40 Latin American women in Toronto who experienced separation from children as a result of migration and argue that Canadian immigration policy and elements of the women’s context of departure lead to the systemic production of transnational family arrangements. Once in Canada, the women dealt with unexpected lengths of separation, the spatial dispersal of social reproduction, and postreunification problems. The absence of a normative framework that could help the mothers make sense of family dispersal meant that their experiences of migration, family separation, reunification and settlement were marked by tension, guilt, isolation and shame.
\end{abstract}




\section{Transnationalizing Families:}

\section{Canadian Immigration Policy and the Spatial Fragmentation of}

\section{Care-giving among Latin American Newcomers}

The turn of the century has been marked by a steady increase in the world's migrant population. At the same time, scholars have noted a growing tendency among newcomers to maintain ties to their home country (Levitt et al., 2003; Portes et al., 1999). Analysts point to multiple factors to explain increasing transnationalization including: greater access to and cheaper cost of communications and travel technology; negative racialization in the host country (Basch et al., 1994); disadvantageous economic incorporation (Landolt, 2001; Portes et al., 2002), new possibilities for capital investment and expansion strategies by migrant elites (Guarnizo, 2003; Ong, 1999; Wong and Ng, 1998); and home country state strategies for encouraging migrants to stay connected to the homeland (Calderón Chelius, 2003; Goldring, 2002; Itzigsohn, 2001; Nyiri, 2001; Ostergaard-Nielsen, 2003; Pe-Pua et al., 1996). What much of this work fails to highlight is that one of the main reasons people maintain transnational ties is because close family members remain in the country of origin.

While transnational families are by no means a new phenomenon, complex factors associated with changes in migration and immigration policies in sending and receiving countries have contributed to a renewed proliferation of spatially ruptured family arrangements. In the case of Canada, a traditional immigrant receiving country, transnational family practices are associated with two migration streams including the $19^{\text {th }}$ century migration of Chinese workers, and more recently, labour migrants from third world countries that enter Canada through temporary worker programmes such as the Seasonal Agricultural Workers Programme and the 
Live-in-Caregiver Programme. In these cases, there has been an explicit understanding that state policy will place restrictions on family reunification and permanent settlement.

Since the 1990s, three shifts in Canadian immigration policy have prompted an expanded proliferation of transnational family arrangements. First, temporary worker programs have been expanded to meet labour market shortages in agriculture and primary extractive industries. In this case, transnational family arrangements are built into the structure of the immigration policy since these migrant worker programmes are tied to long term restrictions on acquiring permanent residence. Second, a new business category was created within the economic entrance class in order to encourage foreign capital investment, particularly from East Asia. The by now well known case of astronaut families is facilitated in this case as an unintended consequence of immigration policy (Waters, 2002; Wong and Ng, 1998).

Third, the government overhauled the Immigration Act of 1978 and in 2002 implemented the Immigration and Refugee Protection Act (IRPA), which consolidated the earlier trend toward harmonization with U.S. immigration policy. The IRPA instituted far-reaching changes in refugee determination, inadmissibility, processing, fees, definitions of family, and so forth. Thus, while the IRPA made it easier to bring common-law and same-sex partners into the country through family reunification provisions, it has also limited family formation within Canada by narrowing the criteria for dependent children, eliminating fiancées, and preventing people on social assistance from sponsoring relatives (Canadian Council for Refugees, 2002). The new processing system also makes family members ineligible for sponsorship if they were not included in a refugee claimant's original application, requires costly and time-consuming DNA testing, and has resulted in a backlog of cases fuelled by administrative delays (Canadian Council for Refugees, 2005). The IPRA introduces family dispersion and transnational family 
arrangements into migration streams - permanent residency and refugee migration - that for the past three decades have been associated with prompt reunification and certain permanent settlement. This policy shift and its apparently unintended consequences raises important questions about the emergence of a two-tiered immigration system in which Canada begins to abandon its framework as a traditional immigrant receiving country (Castles and Davidson, 2000; Sharma, 2006).

In light of this policy shift, our paper analyse the causes and consequences of spatial dispersion for Latin American families living in Toronto. We analyse the data from forty in depth interviews with Latin American mothers who experienced significant and largely unexpected periods of parent-child separation to develop three arguments. First, we trace the micro-level dynamics though which spatially dispersed families negotiate the temporal unpredictability of the Canadian immigration system. Second, we support recent feminist scholarship on transnational family relationships that underscores their tenuous nature and captures the enormous amount of care-work that is required to maintain them. Unexpected spatial ruptures strain family relations, where separation reorganizes and often erodes the migrant woman's maternal authority in ways that last long after reunification. Third, we suggest that spatially dispersed families are largely invisible to Canadian social service providers and consider some of the reasons for their invisibility.

The presentation of findings is organized as follows. First, we review the relevant literature and present the project research design. This is followed by an overview of Latin American migration to Canada with an emphasis on how it differs from the better known US case. The discussion of the contexts of exit and reception that organize this migration system helps to situate the respondents' migration and settlement experiences. Third, we consider the 
ways in which spatial ruptures, particularly between mothers and their children, transform family power structures and intra-family relationships. In the fourth section we touch on the relationship between the respondents and institutions in Canada. This is followed by our concluding remarks.

\section{LOCATING TRANSNATIONAL FAMILIES}

The family is defined as a primary social institution that plays a central role in securing livelihood for individuals throughout the lifecycle, meeting individuals’ affective needs, and serving as a primary arena of socialization, identity formation, and value transmission. The family is not only a structural unit, but also as a series of relationships or a network of individuals bound by an ideology of shared kinship (Stack, 1974). The family, unlike the household, is not necessarily defined by co-residence or spatial proximity and can thus extend across long distances and multiple locations for indeterminate periods of time. The boundaries of the family are therefore not based on ecological or geographic location, but rather on structures of relationships and flows of activities (Fox and Luxton, 2001; Herrera-Lima, 2001).

In the migration process, the family undergoes changes as family members seek to meet individual and group needs within a dramatically changed context. Migration does not dissolve family structures, but redefines and challenges the established codes that organize and give them meaning. Displacement and physical relocation also disrupt the material and discursive arrangements of the family as members find themselves embedded within different economic, social, political, and cultural contexts (Grasmuck and Pessar, 1991). Migration thus produces changing options, modes of negotiation, sources of tension, and sources of power and autonomy for different family members. Gender and generational differences are especially salient dividing lines, defining the particular interests and sources of power of individuals within the 
group. As new situations and conflicts arise, so too emerge novel instruments and strategies for resolving tensions (Boyd, 1996; Hirsch, 2003; Hondagneu-Sotelo, 1994; Wong, 2003).

Pioneer studies of transnational migration recognized the distinct importance of the family for immigrants' border-crossing practices. The family was posed as the matrix from which a layered transnational social life is constructed and elaborated (Basch et al., 1994; Pe-Pua et al., 1996). Family networks were conceived as a key micro-level building block on which other forms of transnational practices and institutions are built (Itzigsohn and Giorguli Saucedo, 2001). Research on the internal workings of transnational families has addressed the relationship between spatial ruptures and transformations in family care-giving strategies, resource circulation, gender and generational role definitions and divisions of labour, as well as the overarching ideologies and normative frameworks that frame family relations (Landolt and Da, 2005; Plaza, 1999; Salazar Parreñas, 2001; Wong, 2003).

Much of the early work on transnational migration, largely U.S.-based (Basch et al., 1994; Portes et al., 1999), emphasized the continuity of social networks and institutions across borders. However, both the broader literature on transnational migration and work focusing on families has largely failed to consider the potential pitfalls and noise that test the limits of social networks. There has also been a tendency to underplay the negative impacts of spatial ruptures on social relations and specifically on the emotional bonds between children and their primary care givers. Exceptions include work by Menjivar (2000), Nolin (2006) and Salazar-Parrenas (2006). In the same vein, a new generation of feminist research on transnational family lives emphasizes their precariousness and points to the enormous amount of care-work that is required to maintain family relations across space, as well as the largely invisible social and emotional costs associated with family separation (Parrenas, 2006; Wong, 2003). 
Comparative analysis reveals the breadth and depth of variation that exists in the types of families that routinely negotiate multi-local, border-crossing relationships. Transnational families exhibit variation based on factors such as: class, race and ethnicity, status, and rural or urban background. Variation also arises depending on the contexts of departure and reception that frame their migratory movements; the geographic location of the different family members and their respective immigration status; and the degree of difficulty they face when crossing national borders. Transnational families also vary in terms of their familiarity with and experience as migrants. Over time the transformations hastened by migration produce normative adjustments in the family, its structures of power and authority, and the social obligations of its different members (Gmelch, 1992; Massey et al., 1998). Such transformations are never without conflicts as tensions often arise in familial negotiations about who will migrate, the long-distance management of migrant wages, and the impact of separations on relations between adults, particularly the conjugal couple (Gledhill, 1995; Hirsch, 2003; Hondagneu-Sotelo, 1992). Nonetheless, families from communities with a migration tradition are able to draw on established migration narratives and practices to weather spatial ruptures. For example, Hondagneu-Sotelo and Avila (1997) document how Latina immigrant domestic workers in Southern California transform the meanings of motherhood to accommodate spatial and temporal separations from their children. Less well-understood is the experience of migrants who are not embedded in migration traditions and specifically of those whose notions of family life do not include normative resources for long-distance motherhood or spatially ruptured family lives, because they are not embedded in transnational social fields where such dispersion may be more widespread. 


\section{RESEARCH DESIGN}

Our research on transnational families is part of a broader project on the incorporation and transnational engagements of Latin Americans in Toronto conducted by the authors under the collaborative title of "Latin American Research Group” (LARG). ${ }^{2}$ This, in turn, has been part of the larger project Social Cohesion and International Migration in a Globalizing Era:

Transnational Solidarities and Newcomer Incorporation in Canada directed by Michael Lanphier of York University.

The themes of the questionnaire ${ }^{3}$ reflect our recognition of the ways in which migration and spatial ruptures challenge the established material and normative order of the family. The themes include: 1) family migration and personal employment history; and 2) relations between the primary caregiver (mothers) and children, the conjugal couple, and the extended family, both during spatial ruptures and, if applicable, in the period of family reunification. The questionnaire challenges informants to discuss conflicts and tensions within the family, and to identify how shifts in the balance of power and authority associated with spatial ruptures were reflected in decision-making about migrating, resource use, care giving, long-term planning, and so forth.

The questionnaire reflects a spatially flexible conceptualization of the family and seeks to identify the everyday dynamics through which families lead transnational lives. The interview begins with a battery of questions that establish the geographic location of informants' immediate and extended family, as well as the type, modality and regularity of communications and resource circulation among family members. This initial mapping exercise made it possible to capture the local and border-crossing dimensions of intra-family relationships, long-distance care giving, and formal and informal support networks. 
We also investigate the institutional landscape in which respondents, as newcomers to Canada and as primary caregivers, are situated. Informants were asked to discuss their relationship with the Canadian education system and with health care services, the character and quality of the resources garnered through formal and informal support networks, and the nature of their participation in different civic activities such as neighbourhood associations, faith-based organizations, labour related associations, and unions.

The sampling strategy reflects both the distinct settlement patterns and modes of incorporation of Latin American immigrants in Toronto, and the emotionally charged nature of the research topic. One of the criteria for respondents to become part of the sample was that they identify as primary caregivers. Our sample of 40 consists entirely of women because we found that although men were willing to discuss their experiences of family separation, they did not identify as primary caregivers. Additional criteria were based on country of origin, on having experienced what informants considered a significant separation from children in the course of migration, and on having children under 18 years of age.

Given the heterogeneity of the Latin American immigrant population in Toronto, and its rapidly changing character away from the traditional source countries of Central and South America (i.e., Chile, Ecuador, El Salvador, and Guatemala) towards new sending countries such as Mexico, Colombia, and Costa Rica, the identification of potential informants was organized around a multi-site quota sampling method with a target of five to seven informants from each of the selected countries: Argentina, Colombia, Costa Rica, Guatemala, El Salvador, Ecuador, and Mexico. Although we had anticipated that recruiting participants would pose a challenge because of the nature of the topic, we did not expect that feelings of shame about abandoning children would complicate recruitment. Our greatest success in recruiting respondents was 
through our participation in church activities and the persuasive intervention of priests and staff at community centers, where we co-sponsored a legal information workshop (Centre for Spanish Speaking Peoples, CSSP) or participated in community meetings (Settlement and Integration Services Organization, SISO).

In the end, we used twelve points of entry. These included community centers that either hosted parenting programs or offer immigrant settlement services for the Spanish-speaking population; Spanish-speaking Catholic and Protestant churches; and settlement workers associated with the Settlement Education Partnership in Toronto ${ }^{4}$ (SEPT Program) who were asked to help identify potential informants. Concurrently, we made use of the Spanish-language media to promote the research and recruit participants and organizing an information session at the Centre for Spanish Speaking Peoples ${ }^{5}$ for Latin Americans whose applications to sponsor their children had been delayed or denied. The two-hour interviews were conducted in Spanish by native speakers in a community centre or in the women's homes.

Table 1 provides a demographic breakdown for the sample. It suggests that the women in our sample were by and large urban, educated, mostly middle-class and some blue collar. The ages of the women we interviewed ranged from 25-54. Most of them were in their 30s. The participants' educational backgrounds were also heterogeneous. Four had little or no education, 21 had some or completed secondary or vocational school, 6 had technical post-secondary school, and 10 had university-level education. The women’s occupations before migrating included professionals (accountant, teacher, lawyer, nurse, doctor, $\mathrm{N}=14$ ), workers in a family business ( $\mathrm{N}=12$ ), and blue-collar (janitor, housekeeper, cashier, $\mathrm{N}=9$ ). Only five of the 40 women interviewed did not work for wages before migrating to Canada. At the time of the 
interview, 24 women did not have paid employment. Of those in the labor market, most were in blue-collar jobs $(\mathrm{N}=16)$ and only two worked as professionals.

Insert Table 1 about here

\section{THE INSTITUTIONAL PRODUCTION OF DISPERSED FAMILIES}

The contexts of exit and reception that organize a migration flow frame settlement experiences (Portes and Böröcz, 1989). In this section we describe the contextual factors that contour Latin American migration to Canada in order to situate the migration experience of the mothers in our study.

\section{Latin American Migration to Canada}

Since the post World War II period, economic insecurity and the search for better livelihood opportunities have been an ongoing reason behind most cyclical and long-term migrations in the region of Latin America. During the 1970s and 1980s, the rise of bureaucratic authoritarian regimes in the Southern Cone and protracted civil wars in Central America forcibly displaced people within countries and across borders. More recently, the effects of neo-liberal economic policies have led people to use existing social networks, or risk migration without them, making international migration an increasingly widespread aspect of life in many rural and

urban settings in Latin America. The growing importance of family remittances to the balance of payments in countries throughout the region reflects not only the prevalence of migration, but also the magnitude of family dispersal and social obligations across borders, as well as the increasing feminization of migration (Guarnizo, 2003; Ramírez et al., 2005).

Canada's relationship to this continent-wide and 100 year old migration system is quite recent and different from the better known migration of Latin Americans to the United States (Massey et al., 1998). Prior to the seventies, immigration from Latin America to Canada was 
negligible due in part to the absence of economic or political strong ties between Canada and the region and geographic distance (Gilbert and Lee, 1986). As a result, Latin Americans account for a smaller share of the stock and flow of Canada's immigrant population. In 2001, immigrants from "the Americas" accounted for $16 \%$ of the foreign born population in Canada. In the same year, the Americas (including Canada) accounted for 54\% of the foreign born population in the United States (Migration Policy Institute, 2004). In stark contrast to the US where Latin American migration is associated with unauthorized entry and patterns of incorporation marked by long term situations of less than full legal status (Menjivar, 2003), in Canada, Latin Americans' modes of entry into the country and their status upon entry are by and large detected, authorized and in many cases government-assisted (cf. Landolt, 2007). Exiles and refugees who left Chile, El Salvador, and Guatemala during the 1970s and 1980s are among Canada’s largest Latin American national origin groups. Indeed, between 1980 and 2001 approximately one third of Latin Americans entered Canada as asylum seekers or recognized refugees. In recent years, they have been joined by refugees from Colombia, and by people leaving contexts characterized by economic as well as personal and social insecurity in countries as varied as Argentina, Mexico, Ecuador, Peru, Brazil and Honduras (Garay, 2000; Goldring, 2006).

Table 2 presents information on Latin American immigrants and non-permanent residents (e.g. refugee claimants, students and temporary workers) in Canada, based on data from the 2001 census.

Insert Table 2 about here

Table 2 shows the importance of Mexican, Salvadoran, and Chilean immigrants in Canada. The data on temporary residents also points to the significance of Mexican temporary workers and students, and Colombian refugee claimants. 


\section{Uncharted Journeys to Canada}

Table 3 provides a migration profile of our informants. In the case of our informants, migration was often a step process. Many of the women emigrated in response to what they perceived as a slow erosion of their quality of life. Respondents mentioned limited economic opportunities, but also a generalized situation of political violence, crime, and public insecurity as push factors for emigration. These conditions often dovetailed with a personal crisis in their lives, which for a third of the sample, included an unbearable home life marked by domestic violence and fears of retaliation and ongoing harassment by an abusive spouse. Participants spent time in the United States prior to arriving in Canada and had left family members in the United States. Before migrating, only 33\% of the women had friends or family living in Canada. There was a great deal of variation in the legal status of informants upon entry to Canada. Twelve of the women entered as permanent residents, either through family sponsorship or on their own. Fifteen entered under a refugee program or made an asylum claim upon arrival. The rest were sponsored by family or came as tourists and students. None of our informants, however, entered Canada undetected, although some had over-stayed their visas.

\section{Insert Table 3 about here}

By and large, respondents were not embedded in strong migration traditions, although the majority did draw on resources garnered through migration networks to exit their country of origin. Only thirteen of the women had any family or friendship ties in Canada that might have helped them select Canada as their destination of choice. A noteworthy number of respondents obtained information about Canada and its immigration process through weak ties-a travel agent, a neighbour, or the Internet. The notion that Canada is an immigrant-friendly country and that there is respect for women's rights and protection against spousal abuse were common 
themes in this discussion. Women who had experienced spousal abuse reported having heard that Canada was receptive to women in their situation. One respondent explains:

I went to live in the United States for a year and saw it was very difficult to bring my children because they did not have a visa. People said that in Canada it was faster, so I said, “Okay, I’m going to Canada so that the family can be reunited.” (Ecuadorian; now reunited with her children).

The mothers in our study opted to leave their children behind for a variety of reasons.

They considered the trip too dangerous and requiring a fast pace, or the children did not have the legal documents to leave their country or enter Canada, or were not the offspring of the emigrating couple. In some cases, as the mothers explained, their children were older and chose to stay alone to manage their own affairs without plans for reunification. Regardless of their reasons, the overwhelming majority of our respondents drew on the classic immigrant discourse about “the search for a better future for one’s children” to explain their decision to leave home without their children. They emphasized that the decision to leave the children in the home country was made under duress but was considered the best possible arrangement for the longterm well-being of the family.

Quite significantly, the mothers did not expect to face, did not plan for and were not prepared emotionally or economically for the long periods of separation from their children. In contrast to their expectations, the mothers were separated from their children for significant periods of time, as shown in Table 3. The majority of the women, approximately $88 \%$, remained in separation for periods ranging from seven months to five years. Four of the informants revealed lengthier separations of six to eight years. At the time of the interviews (summer 2004), half of the women remained separated from their children. 


\section{DISPUTED MATERNAL AUTHORITY: THE TENSIONS OF CROSS-BORDER CAREWORK}

Once the women were faced with family separation, they struggle to fulfill their role as mothers in new ways. In this section we examine the intersections between geographic separation and inter-family dynamics by discussing: 1) transnational exchanges; 2) long distance parenting and loss of maternal status; and, 3) the uncertainties of reunification.

\section{Transnational Exchanges}

The mothers in our study engaged in transnational dialogues and resource exchanges with non-migrant family members in an effort to maintain their place and role as mothers, daughters, and spouses. The circulation of ideas and information across borders, particularly with relatives, was an important aspect of all of the respondents' lives. All of the women relied on regular communication with family members outside Canada, including exchanging letters, e-mails, often with photos attached, chat sessions, videos, photographs, gifts and money. The most common topics of discussion related to childrearing and school issues, followed by work and money.

However, long-distance communication was often fraught with difficulty. Some of our respondents succeeded in maintaining effective communication. Mrs. Marcos, who was separated from her children for 16 months, was generally satisfied with her contact with the children.

The only thing I expect from them is that they keep me informed about everything so there is not a situation that all of a sudden I should know about something, I want them to keep me informed. That is the only thing I ask of them. (Colombian; separated from children for two years; reunification planned) 
The women were also part of extended family networks that involved the regular circulation of goods, resources, individuals, and information across the borders of nation-states. These exchanges took the form of both money received from relatives in the home country and money sent to children and other relatives outside Canada. Although much of the discussion on remittances focuses on the flow of resources from North to South, ${ }^{6}$ nine of the women we interviewed had received money from their non-migrant parents and siblings. This type of exchange ranged in frequency from every few months $(\mathrm{N}=4)$ to a single occurrence $(\mathrm{N}=5)$ and was intended to assist with such matters as paying a deposit for rent or telephone services. The amounts ranged from $\$ 150$ to several thousand dollars, while the average size of remittance from South to North was $\$ 895.00$.

The majority of remittances sent by the mothers in this study went towards the care of their children. Most of the mothers $(\mathrm{N}=31)$ said they sent remittances on a regular basis with yearly amounts ranging from $\$ 100$ to $\$ 12,000$ per year (mean of $\$ 3,062$ ). A variety of methods were used to send the money, with the most commonly used services being Western Union, Vigo and Gigante Express. Respondents also used small family grocery stores. Over two-thirds of the mothers $(\mathrm{N}=26)$ sent money to other relatives as well, which commonly went towards basic living expenses, emergency situations, and gifts for special occasions.

\section{Long Distance Parenting and Loss of Maternal Status}

The separations experienced by the families in our study led to a reconfiguration of family networks and to a transformation in women's power and authority within their families. This happened despite the mothers' best efforts to maintain communication and stay informed. The picture painted by our informants is one in which the length of separation was completely unexpected. Temporary care arrangements became permanent and in the process there was a 
relinquishment of authority and an erosion of maternal status.

During the period of separation, other family members assumed care giving responsibilities including grandparents $(\mathrm{N}=22)$, the father $(\mathrm{N}=10)$, as well as other relatives, friends, and neighbours $(\mathrm{N}=7)$. In one case the children stayed alone in the family home with the supervision of two aunts who lived nearby. The following quote captures the breakdown of authority and parental status that often accompanied long distance mothering arrangements. My parents are the ones that are dealing with my child because I am so far that I don't see the day to day issues. My parents say, “Let’s do this in this way.” They don’t want to give me problems, so they don't tell me the little things, little things like that my son used to cry every night before falling asleep. (Colombian; sent her child ahead to Boston; now reunited in Canada)

In interposing themselves between mother and child, the relatives were, in effect, displacing the mother. Indeed, in this case the grandparents had reportedly come to consider the child as their own and wanted to protect him from being upset. Thus, mothers would loose their direct connection with their children.

The process of migration also shifted the generational balance of power and often gave children greater autonomy over decision-making than they previously had. Three patterns were evident. In some cases, children took care of their own affairs. These children were often more or less on their own, but staying with a family member who exercised little authority or supervision. In some cases, this was due to the absence of an adult that was willing and able to step in to act as the authority figure at the time of separation. In others, the grandparents and other caregivers provided basic love, food, and shelter. However, they provided less guidance and discipline than expected by the mother, and they did not take on parent-like authority. In a 
second set of cases, the caregivers exercised some control but were inclined to spoil and indulge the children. The behaviour of children reflected such changes in authority:

Thanks to my sister, he became fussy about eating. That is, he became more picky. Before, he would eat everything. But with my sister, I don’t know what happened; he became very fussy about eating. (Mexican; now reunited with her son)

In a third set of cases, the grandparents enforced strict traditional rules, with practices such as spanking, to the discomfort of the mothers:

In Mexico people are accustomed to the idea that the children get spanked once in a while and I did not agree with that...But I could not say anything to my mother because that was what she was used to. She raised all of her children that way and even if I tell her and tell her she will always think she is right. Because she says, "If I got good results with that then that is best." I never said anything to her. She did not beat him but she would give him a spank. There was no point in interfering with her decisions. (Mexican; sent back her Canadian-born child)

The mothers did not want to interfere with the decisions taken by the new primary caregiver, but often areas of disagreement surfaced, typically over issues of discipline and child treatment.

In some cases the mothers were able to preserve emotional ties with their children and other family members left behind. However, estrangement was fairly common. Another reason for estrangement was the frequent breakdown of direct telephone contact. The cases we are referring to involve children who were unable or unwilling to come to the phone or whose relatives insisted on taking messages. Although the women in our sample tried to maintain communication this was not always easy or possible. 
During those times when I was first here I would call my child every day. It was incredible. I only worked to be able to call him, to send him money and to pay for my rent and the bus fare. The father was vague and would not answer my calls. He would say that the child was not there, that he was busy, all kinds of excuses. Sometimes I would talk to him but it was tense and rushed. After a long time I found out that my son was not even living with his father but with his grandmother. During that entire time, nobody told me anything and I was not able to communicate well with my son.

(Colombian; reunification will not occur as son is too old)

Difficulties in speaking to the children on the phone were also common with a number of adolescent children who had already assumed economic and self-directing responsibilities when the parents were absent. They had found new networks of support and their decisions about sexual activity, career planning, and normative behaviour were no longer discussed with the mothers. In fact, a new family configuration had formed which the mothers only recognized after the fact. All of these situations diminished the women's parental authority.

\section{The Uncertainties of Reunification}

Reunification brought with it unexpected challenges and difficulties. At the time of our study, half of the forty mothers had not been reunified with their children. The reconfiguration of authority structures frequently gave rise to further problems. Mothers and children had become strangers and the child's willingness and ability to re-attach was called into question, since the "reunification" was, in effect, a second major rupture of the child's attachment.

After months or years of infrequent long distance contact, estrangement occurred and became evident when reunification eventually happened. Norma told us about the reunification with her son after being separated for three years: 
I felt like I was hugging a nephew, or that I was looking at a nephew, but not my own child. He was different, his thoughts, his way of behaving. At first he was happy, but then he was angry. "Why did you leave me? Why did you take so long?" I had thought my paperwork would take a year. I told him, "In one year I'll be with you.” But it took three years. So he said, “Why did you leave me?” I found not only a stranger, but an angry stranger. (Mexican; now reunited with her son).

Another mother expressed her sense of loss as follows:

When they finally arrived, they were changed. I saw them so big, a little bit disobedient and a bit "malcriados" (rude, not well brought up). They took advantage of my kindness because they had not seen me for so long. I wanted to please them because of not having them for so long, so they became a bit rebellious. (Costa Rican; now reunited with children)

It was not uncommon for the reunification to fail. In some cases, the child presented so many challenges that the only practical solution seemed to be to send them back to the home country. In sum, there were often permanent shifts in the family configuration such that persons who once were central in decision-making around the children no longer occupied that status. Mothers often lost their role as primary decision-makers and it was not uncommon to find some degree of authority reverting to the grandparents. In turn, however, the grandparents did not appear to exercise the same tight discipline as the parents had; thus the children, of necessity, became more self-directed. Family reunification generated a new host of uncertainties in maternal authority. 


\section{SETTLEMENT: SHAME AND SOCIAL ISOLATION}

The experiences of the mothers, from the decision to migrate through the period of separation and during the process of reunification, were overwhelmingly marked by shame, guilt, and hopelessness. Part of the reason for the shame and stigma had to do with respondents' concepts of family and the importance they placed on physical closeness and face-to-face contact with their children.

Maybe this is why I talk to them so much about being lonely, because maybe I do talk too much. But I am lonely because I was so used to living my life with my children. The family nucleus was the most important thing for me. The most important thing in the world. And to all of a sudden come to be dismantled like this, from one day to the next it is all over and we are separated....It is hard.... Sometimes I feel guilty and ask myself if it was all worth it, if it was really worth it to come here leaving three children behind, or is it that only money is important? Or is it only important to be here? And what about human values and respect? What is the place of family then? These are questions that I ask myself all the time. (Colombian; separated for two years; reunification planned)

The mothers viewed the separations from the children as breaking a cultural norm and depriving their children of something that could not be replaced. The embarrassment felt by many mothers was clearly expressed by Mrs. Marcos:

It is not that I was rich in my country but I had a maid. So when I call them they ask me, “Mommy, what are you doing?” "I’m taking care of some children.” And then my youngest, who is the most attached to me, says: "You're there, taking care of children, and we're here alone.” (Colombian; separated for two years; reunification planned) Shame and stigma also induced the mothers to keep themselves off the radar screens of 
social service agencies. One mother described the harm of separation on her child and her embarrassment and guilt in disclosing information about it as follows:

I will never tell anyone that my child left for two years and now has returned. When he bites or hits other children at school, I cannot tell the truth. They tell me he needs to play with more children so that he can integrate himself, but they don't know that the truth is that he was not with me. I can't tell them he is rebellious for that reason. Or that he doesn't want to eat or pay attention to me for that reason. The only person I can tell is the paediatrician, so I say, “He won’t eat, what can I do?” But that is only because it is about his health. (Mexican; sent back her Canadian-born child; now reunited) As was evident when we were attempting to recruit participants for the study, the women were not accessing the mainstream community-based services designed for mothers and children. In our data collection phase, we learned that the mothers had weak social support networks in Toronto and tended to avoid formal assistance agencies. They generally did not turn to local friends, relatives, lawyers, immigrant organizations, or therapists for help. When they accessed services they did so in an ad hoc way manner and motivated by the trust they placed on a specific individual. As one mother explained:

There is a very good woman at the school who belongs to a community center but is placed in the school. She is Hispanic. She helped us so much. I could talk to her. She helped my son get into the ESL classes, because that is not easy. She also took us to a place where we could get winter clothing because we had no money and it was so cold. (Costa Rican; fled spousal abuse; now reunited) 
Many of the women turned to the church for support and strength and confided in their priest. Some looked to their family doctor or paediatrician, and a few found ad-hoc connections in other ways.

My emotions were terribly upsetting for me. A lot of depression, crying, and sadness. The only thing that helped was going to church. There were a lot of families in the same situation, and we supported each other, and told each other to be patient. (Mexican; sent back her Canadian-born child; reunited two years later)

For most participants, the social functions of their religious faith were primary. Priests and their assistants often made extensive efforts to create a welcoming atmosphere in the church. Going to church became the only regular social contact and was a common practice, even among those who had previously not given much time to practicing their religion. At church services and other functions, the women had access to various types of support and were in contact with the everyday signs of their culture. The importance of the church was reflected in the fact that, in many cases, we made original contact with the participants only because they were known to the local priest.

In summary, the women were isolated, often depressed, and tended to lack access to social services and support. Their coping strategies, rooted in shame and guilt, resulted in interfamilial difficulties, which marginalized them further. Many found it difficult to acknowledge separation from children when seeking services from Canadian institutions, but did find solace in talking to priests, pediatricians, and school personnel whom they felt they could trust. 


\section{CONCLUSION}

Migration scholars have noted the salience of transnational family arrangements in the context of globalization, human mobility and the greater accessibility of travel and communications technology. As part of an effort to make transnational practices more visible, this work has tended to emphasize the seamless production and maintenance of flexible transnational social relations. While sympathetic to this body of research, we join recent feminist transnational scholarship that points to the care and emotional work that goes into maintaining transnational family ties, as well as their fragility and implications. Our work illustrates the difficulties experienced by parents and caregivers, in our case mothers, under circumstances of geographic separation from children. Our specific contributions involve showing how the Canadian context of reception, particularly immigration policy, systemically produces transnational family arrangements, and how Latin American mothers in this setting generally lack the social networks, normative frameworks and institutional resources for coping with the separation. As a result, their individualized guilt and shame make it difficult for them to disclose information about their situation with service providers who, in turn, are often ill equipped to recognize the possibility and implications of transnational arrangements.

Transnational family arrangements are not new. In Canada, this pattern has been documented by scholars of Chinese immigration and analysts of temporary worker schemes. Our discussion has shown how contexts of exit and reception for Latin American immigrants and refugee claimants in the Greater Toronto Area contribute to the production of transnational families. More specifically, recent changes to Canadian immigration policy are institutionalizing the geographic separation of family members in immigration entrance categories that used to accommodate the immigration of intact (nuclear) families. Immigrants and refugees who used to 
enter with authorization and family members, or who experienced relatively short delays in reunification, are now finding it more difficult and costly to enter Canada. Newcomers now face long and usually unexpected delays to family reunification in Canada.

One conclusion of our work is that policy makers and others need to recognize the role played by policy in generating and perpetuating family arrangements that span borders. Rather than seeing transnational families as an outcome produced exclusively by parents' decisions to leave children behind, they must also be seen as generated by insufficient, out of date or incorrect information; lack of resources; the need to leave a negative situation; and/or the assumption that separation will be temporary and short. Because restrictions on authorized immigration and government-assisted refuge have limited the opportunity for whole family migration, increasing numbers of people will find themselves in situations of family separation. Policy changes also make reunification more problematic and often unattainable.

The Canadian context differs from that of the United States in various ways, which underscores the relevance of comparative research. In Canada, recent Latin American immigrants face the challenge of not having the normative frameworks and social networks that might allow them to cope with family separation and the complications in parent-child relations that generally follow. This is quite different from the United States, where transnationalized community networks generated initially through largely unauthorized and seasonal or circular migration patterns generate different expectations and normative frameworks. This points to a second way in which our findings may be relevant to policymakers and service providers. Rather than assuming that people will be able to deal with difficult situations by drawing on individual or community resources, service providers would be advised to include information about the causes and consequences of family separation, and problems associated with 
reunification, in their training.

Our work underscores the importance of distinguishing between the causes behind the original decision to leave a child or children behind, and the factors that eventually result in a protracted separation from the primary caregiver or a failed family reunification. The former decision reflects the options available to a family based on their context of departure, however, the latter are largely a result of the Canadian context of reception, including the immigration policies that impinge on family migration and reunification. Contributing to the protracted separations were the parents' lack of family contacts in Canada and their unawareness of the reality underlying Canada’s official "friendliness" to refugees.

While popular opinion and official policy emphasize family migration, our research shows that such assumptions about timely family reunification do not hold. Our analysis of Canadian immigration policy and the way it has been experienced by the women in our study shows that family dispersal is becoming part of the "new normal" rather than an exception. Our data indicate that it is far from clear that settlement and reunification of the whole family is the usual and expected outcome, even over the long run. As a result, it is important to analyze the dynamics of the separation period and shifts in familial authority structures, which often becomes permanent. These structures play an important role in the continuing reproduction of dispersed family configurations. Their hindrance and subversion of established family structures and transactions adds a further dimension to the families' struggle to survive as a family. Efforts to maintain families in the new, transnational configurations take a toll on the well-being of families and the hopes and motivations of migrant mothers. Most importantly, we have shown that over time, these women often come full circle. In their homeland they lacked authority outside of the childrearing realm and they faced gendered oppression in many forms. For many, 
coming to Canada represented an assumption of agency. As expected reunification becomes postponed, bogged down, or happens in a dysfunctional way, women see their goals receding. Further, women begin to feel, in the face of resistance from other family members and their own children, that they are unable to adequately fulfill their mothering responsibilities. Indeed, they may be accused of abdicating parenting by the fact of having taken the step of migrating. In these circumstances, women often become depressed. Many of the women found themselves once more in a hopeless and disempowered situation, this time without recognition of maternal authority and the successful mothering of their children.

Public policy based on the chimera of reunification has the expected failings in the above circumstances. Women such as those we spoke to, were often invisible to government bodies and social service agencies. In many cases, shame made it hard for women to disclose separation and problematic intra-family dynamics. Women who did make connections with social service providers generally did so only on an ad-hoc basis. Even where the family situation was momentarily visible, the operating assumption of most social agencies has been that reunification marks the end of any serious need for further services or public support. Our analysis suggests that it is essential that policy planners deal with the ongoing reality of transnational families such as those that we described above, and which others have recounted in moving detail. The presence of social services must be noticed and felt by the women. Social services can make connections if they operate in complementary fashion with existing support networks of friends and communities, such as there may be. Health professionals are well-placed placed to play crucial, intermediary roles in connecting those in "embarrassing” family situations and other professional helpers. Teachers, child-care staff, and priests are often in positions of trust. It is a lesson of this study that only in the presence of trusted confidants can meaningful information be 
ascertained. It is far too easy for social workers, teachers, and others to have a seriously incomplete or misleading overall picture of the family situation (Bernhard and Freire, 1996). Often there is a simple failure to envision possibilities and to make polite and reasonable inquiries.

There is fertile ground for further research, including comparative work, on families in the context of migration. Academics, policy makers, service providers and activists would benefit from exchanges on this topic. Future work needs to take into account the role of public policy in producing transnational family arrangements. While we need to look at dispersed or transnational families as potentially enduring social forms, there is also reason to be concerned with the ongoing human cost of these arrangements. All family configurations involve tension, unequal power, and negotiation; some are more problematic than others. We are not supposing an idealized picture of a united, settled family. However, we argue for recognizing the social policies that produce ruptured family arrangements, as well as their social consequences. This study provides elements for broadening the discussion.

end. 


\section{REFERENCES}

Basch, L., N. Glick-Schiller, and C. Szanton-Blanc

1994 Nations Unbound: Transnational Projects, Postcolonial Predicaments and

Deterritorialized Nation-States. Amsterdam: Gordon and Breach.

Bernhard, J.K.and M. Freire

1996 "Latino refugee children in childcare: A study of parents and caregivers," Canadian Journal of Research in Early Childhood Education, 5(1):59-71.

Besserer Alatorre, J.F.

2002 "Contesting Community: Cultural Struggles of a Mixtec Transnational Community."

Ph.D diss., Anthropologyx, Stanford, CA: Stanford University.

Boyd, M.

1996 "Family and personal networks in international migration: Recent developments and new agendas." In The sociology of migration. Ed. R. Cohen. Cheltenham, UK: Brookfield. Pp.297-328.

Calderón Chelius, L.

2003 Votar en la Distancia: La extensión de los derechos políticos a migrantes, experiencias comparadas. Mexico, D.F.: Contemporanea Sociología \& Instituto Mora.

Canadian Council for Refugees

2002 Immigrant and Refugee Protection Act: Overview of Key Provisions. Montreal: Canadian Council for Refugees. http://www.web.net/ ccr/irpatraining.html

2005 Families never to be united: Excluded family members. Montreal: Canadian Council for Refugees. http://www.web.net/ ccr/excludedfam.html

Castles, S.and A. Davidson

2000 Citizenship and migration : globalization and the politics of belonging. Basingstoke: Macmillan.

Fox, B.and M. Luxton

2001 "Conceptualizing Family." In Family Patterns, Gender Relations. Ed. B. Fox. Toronto: Oxford University Press.

Garay, E.

2000 Integrated Settlement Planning Project: Social, economic and demographic profile Hispanic community. Toronto: Hispanic Development Council.

Gilbert, J.and M. Lee

1986 The Bridge Between Canada and Latin America. Coquitlam, BC: Two Thirds Editions.

Gledhill, J. 
1995 Neoliberalism, Transnationalization and Rural Poverty: A Case Study of Michoacán, Mexico. Boulder, CO: Westview Press.

Gmelch, G.

1992 Double passage : the lives of Caribbean migrants abroad and back home. Ann Arbor: University of Michigan Press.

Goldring, L.

2002 "The Mexican State and Transmigrant Organizations: Negotiating the Boundaries of Membership and Participation," Latin American Research Review, 37(3):55-99.

2006 "Latin American Transnationalism in Canada: Does It Exist, What Forms Does It Take, and Where Is It Going?." In Transnational Identities and Practices in Canada. Ed. V. Satzewich and L. Wong. Vancouver: University of British Columbia Press.

Grasmuck, S.and P.R. Pessar

1991 Between Two Islands: Dominican International Migration. Berkeley and Los Angeles: University of California Press.

Guarnizo, L.E.

2003 "The Economics of Transnational Living," International Migration Review, 37(3):666700 .

Herrera-Lima, F.

2001 "Transnational Families: Institutions of Transnational Social Spaces." In New transnational social spaces : international migration and transnational companies in the early 21st century. Ed. L. Pries. New York: Routledge. Pp.77-92.

Hirsch, J.S.

2003 A courtship after marriage : sexuality and love in Mexican transnational families.

Berkeley: University of California Press.

Hondagneu-Sotelo, P.

1992 "Overcoming Patriarchal Constraints: The Reconstruction of Gender Relations among Mexican Immigrant Women and Men," Gender and Society, 6(393-415).

1994 Gendered transitions : Mexican experiences of immigration. Berkeley: University of California Press.

Hondagneu-Sotelo, P.and E. Avila

1997 "'I am here but I am there": The meanings of Latina transnational motherhood," Gender and Society, 11(5):548-571.

Itzigsohn, J. 
2001 "Immigration and the boundaries of citizenship: The institutions of immigrants' political transnationalism," International Migration Review, 34(4):1126-1154.

Itzigsohn, J.and S. Giorguli Saucedo

2001 "Immigrant Incorporation and Sociocultural Transnationalism," International Migration Review, 36(3):766-799.

Landolt, P.

2001 "Salvadoran Economic Transnationalism: Embedded Strategies for Household Maintenance, Immigrant Incorporation, and Entrepreneurial Expansion," Global Networks: A Journal of Transnational Affairs, 1(3):217-241.

2007 "The Institutional Landscapes of Salvadoran Refugee Migration: Transnational and Local Views from Los Angeles and Toronto." In Organizing the Transnational: The Experience of Asian and Latin American Migrants in Canada. Ed. L. Goldring and S.V. Krishnamurti. Vancouver: University of British Columbia Press. Pp.286-309.

Landolt, P.and W.W. Da

2005 "The Spatially Ruptured Practices of Transnational Migrant Families: Lessons from the Case of El Salvador and the People's Republic of China," Current Sociology, 53(4):625653.

Levitt, P., J. DeWind, and S. Vertovec

2003 "Transnational Perspectives on International Migration: An Introduction," International Migration Review, 37(3):565-575.

Massey, D., J. Arango, G. Hugo, A. Kouaouci, A. Pellegrino, and J.E. Taylor

1998 Worlds in Motion: Understanding International Migration at the End of the Millenium. New York City: Oxford University Press.

Menjivar, C.

2003 "Living In two worlds? Guatemalan-origin children in the United States and emerging transnationalism.," Journal of ethnic and migration studies.:531-552.

Menjívar, C.

2000 Fragmented Ties: Salvadoran Immigrant Networks in America. Los Angeles: University of California Press.

Migration Policy Institute

2004 Migration Information Source. Global Data Center. Canada: Stock of foreign-born population by country of birth, various years, 1991 to 2001.: Migration Policy Institute. http://www.migrationinformation.org/GlobalData/countrydata/data.cfm

Nolin, C.

2006 Transnational ruptures : gender and forced migration Burlington, VT: Ashgate. 
Nyiri, P.

2001 "Expatriating is patriotic? The discourse on 'new migrants' in the People's Republic of China and identity construction among recent migrants from the PRC.," Journal of Ethnic and Migration Studies, 27(4):635-653.

Ong, A.

1999 Flexible citizenship : the cultural logics of transnationality. Durham, NC: Duke University Press.

Ostergaard-Nielsen, E.K.

2003 International Migration and Sending Countries. New York City: Palgrave Macmillan.

Parrenas, R.

2006 Children of global migration : transnational families and gendered woes Stanford, CA: Stanford University Press.

Pe-Pua, R., C. Mitchell, R. Iredale, and S. Castles

1996 Astronaut families and parachute children: The cycle of migration between Hong Kong and Australia. Canberra: AGPS.

Plaza, D.

1999 "Transnational Grannies: The changing family responsibilities of elderly African Caribbean-born women living in Great Britain," Social Indicators Research Journal, 11(7):180-201.

Portes, A.and J. Böröcz

1989 "Contemporary Immigration: Theoretical Perspectives on Its Determinants and Modes of Incorporation," International Migration Review, 23(3):606-630.

Portes, A., L.E. Guarnizo, and P. Landolt

1999 "The Study of transnationalism: pitfalls and promise of an emergent research field," Ethnic and Racial Studies, 22(2):217-237.

Portes, A., W. Haller, and L. Guarnizo

2002 "Transnational Entrepreneurship among Latin Immigrant Groups in the U.S.," American Sociological Review, 67(2):278-298.

Ramírez, C., M. García Dominguez, and J. Míguez Morais

2005 Crossing Borders: Remittances, Gender and Development: United Nations International Research and Training Institute for the Advancement of Women (UN-INSTRAW). http://www.uninstraw.org/en/images/stories/remmitances/documents/crossing_borders.pdf

Salazar-Parrenas, R. 
2006 Children of global migration : transnational families and gendered woes Stanford, CA: Stanford University Press.

Salazar Parreñas, R.

2001 "Mothering From a Distance: Emotions, Gender and Inter-Generational Relations in Filipino Transnational Families.," Feminist Studies, 27(2):361-390.

Sharma, N.

2006 Home economics : nationalism and the making of 'migrant workers' in Canada Toronto: University of Toronto Press.

Stack, C.

1974 All Our Kin: Strategies for Survival in a Black Community. New York City: Harper Torchbooks.

Statistics Canada.

2003. Immigrant Status and Period of Immigration (10A) and Place of Birth of Respondent (260) for Immigrants and Non-permanent Residents, for Canada, Provinces, Territories, Census Metropolitan Areas 1 and Census Agglomerations, 2001 Census - 20\% Sample Data. Cat. No. 97F0009XCB2001002. Ottawa: Census of Canada.

Waters, J.

2002 "Flexible Families? 'Astronaut' Households and the Experiences of Lone Mothers in Vancouver, British Columbia," Social and Cultural Geography, 3(2):117-134.

Wong, L.and M. Ng

1998 "Chinese Immigrant Entrepreneurs in Vancouver: A Case Study of Ethnic Business Development," Canadian Ethnic Studies, 30(1):64-85.

Wong, $\mathrm{M}$.

2003 "Borders that separate, blood that binds: The transnational activities of Ghanaian women in Toronto." Ph.D diss., Geography, Toronto: York University. 


\footnotetext{
${ }^{1}$ A number of people assisted us in recruiting respondents for this study. We are grateful to them and to the women who shared their experiences of family separation. Delmy Xiomara Peraza, Joana Londoño, Patricia Diaz and Paola Bohórquez provided research assistance at various stages of this project.

${ }^{2}$ The Social Cohesion project website includes sections on the Latin American Research Group (LARG): http://www.yorku.ca/cohesion/index.htm.

${ }^{3}$ The complete questionnaire can be viewed at: http://www.yorku.ca/cohesion/LARG/html/families.htm\#Research

${ }^{4}$ The SEPT program is sponsored by Citizenship and Immigration Canada. Forty-eight roaming school settlement workers attend to the newcomer population in seventy-four schools across the city.

${ }^{5}$ The CSSP is one of the oldest multi-service agencies to provide services in Spanish, tailored for Spanish speakers. Other multi-service agencies have Spanish-speaking staff, but they are not “ethno-specific.” Other ethno-specific agencies aimed at Latin Americans do exist, but they generally focus on particular issues or populations (such as domestic violence or women). If churches were seen as multi-service agencies, they would join the list headed by the CSSP.

${ }^{6}$ Federico Besserer's work (2002) demonstrates the importance of south-north and north-north remittances. See Besserer Alatorre, J.F. 2002 "Contesting Community: Cultural Struggles of a Mixtec Transnational Community." Ph.D diss., Anthropologyx, Stanford, CA: Stanford University.
} 


\begin{tabular}{|c|c|c|c|c|c|c|c|c|c|}
\hline \multicolumn{10}{|c|}{$\begin{array}{c}\text { Table } 1 \\
\text { Demographic Profile of Respondents by Country of Origin }\end{array}$} \\
\hline & & Colombia & Costa Rica & Ecuador & El Salvador & Guatemala & Mexico & & tal \\
\hline & & & & & & & & $\mathbf{N}$ & $\%$ \\
\hline \multirow{4}{*}{ Current age } & $25-34$ & 4 & 3 & 2 & 1 & 1 & 3 & 14 & $35.0 \%$ \\
\hline & $35-44$ & 6 & 3 & 1 & 5 & 2 & 3 & 20 & $50.0 \%$ \\
\hline & $45-54$ & 0 & 0 & 3 & 1 & 2 & 0 & 6 & $15.0 \%$ \\
\hline & Total & 10 & 6 & 6 & 7 & 5 & 6 & 40 & $100.0 \%$ \\
\hline \multirow{6}{*}{ Education } & Primary school or less & 0 & 2 & 0 & 1 & 1 & 0 & 4 & $10.0 \%$ \\
\hline & $\begin{array}{l}\text { Secondary or vocational } \\
\text { school incomplete }\end{array}$ & 3 & 2 & 2 & 1 & 2 & 1 & 11 & $27.5 \%$ \\
\hline & $\begin{array}{l}\text { Secondary or vocational } \\
\text { school }\end{array}$ & 2 & 0 & 3 & 3 & 0 & 1 & 9 & $22.5 \%$ \\
\hline & $\begin{array}{l}\text { Technical postsecondary } \\
\text { school }\end{array}$ & 2 & 0 & 0 & 1 & 1 & 2 & 6 & $15.0 \%$ \\
\hline & University level or higher & 3 & 2 & 1 & 1 & 1 & 2 & 10 & $25.0 \%$ \\
\hline & Total & 10 & 6 & 6 & 7 & 5 & 6 & 40 & $100.0 \%$ \\
\hline \multirow{3}{*}{$\begin{array}{l}\text { Marital status } \\
\text { before } \\
\text { migration }\end{array}$} & Single & 5 & 4 & 2 & 3 & 1 & 2 & 17 & $42.5 \%$ \\
\hline & Married & 5 & 2 & 4 & 4 & 4 & 4 & 23 & $57.5 \%$ \\
\hline & Total & 10 & 6 & 6 & 7 & 5 & 6 & 40 & $100.0 \%$ \\
\hline \multirow{6}{*}{$\begin{array}{c}\text { Primary } \\
\text { Occupation in } \\
\text { Country of } \\
\text { Origin }\end{array}$} & Management and Business & 2 & 1 & 1 & 0 & 0 & 2 & 6 & $15.0 \%$ \\
\hline & Professional Service & 4 & 1 & 2 & 3 & 2 & 1 & 13 & $32.5 \%$ \\
\hline & Sales & 1 & 1 & 0 & 0 & 2 & 0 & 4 & $10.0 \%$ \\
\hline & Blue Collar & 1 & 3 & 3 & 3 & 0 & 2 & 12 & $30.0 \%$ \\
\hline & Homemaking & 2 & 0 & 0 & 1 & 1 & 1 & 5 & $12.5 \%$ \\
\hline & Total & 10 & 6 & 6 & 7 & 5 & 6 & 40 & $100.0 \%$ \\
\hline
\end{tabular}


Table 2. Place of Birth for Immigrants and Non-Permanent Residents in Canada from Selected Countries in Latin American and the Caribbean, 2001Census.

\begin{tabular}{|c|c|c|c|c|c|c|}
\hline & $\begin{array}{c}\text { Total - } \\
\text { Immigrants } \\
\text { and non- } \\
\text { permanent } \\
\text { residents }\end{array}$ & $\%$ & $\begin{array}{l}\text { Immigrant } \\
\text { population }\end{array}$ & $\%$ & $\begin{array}{l}\text { Non- } \\
\text { Permanent } \\
\text { Residents }\end{array}$ & $\%$ \\
\hline $\begin{array}{l}\text { Total - Place of birth of } \\
\text { respondent, all countries }\end{array}$ & $5,647,125$ & & $5,448,480$ & & 198,640 & \\
\hline Costa Rica & 2,500 & $1.01 \%$ & 2,230 & $0.97 \%$ & 270 & $1.44 \%$ \\
\hline El Salvador & 39,200 & $15.83 \%$ & 38,460 & $16.80 \%$ & 740 & $3.95 \%$ \\
\hline Guatemala & 14,095 & $5.69 \%$ & 13,680 & $5.97 \%$ & 415 & $2.22 \%$ \\
\hline Honduras & 4,505 & $1.82 \%$ & 4,340 & $1.90 \%$ & 170 & $0.91 \%$ \\
\hline Mexico & 42,740 & $17.26 \%$ & 36,225 & $15.82 \%$ & 6,525 & $34.83 \%$ \\
\hline Nicaragua & 9,535 & $3.85 \%$ & 9,380 & $4.10 \%$ & 155 & $0.83 \%$ \\
\hline Panama & 2,520 & $1.02 \%$ & 2,400 & $1.05 \%$ & 125 & $0.67 \%$ \\
\hline Cuba & 5,320 & $2.15 \%$ & 4,940 & $2.16 \%$ & 385 & $2.05 \%$ \\
\hline Dominican Republic & 5,155 & $2.08 \%$ & 4,965 & $2.17 \%$ & 190 & $1.01 \%$ \\
\hline Puerto Rico & 260 & $0.10 \%$ & 245 & $0.11 \%$ & 15 & $0.08 \%$ \\
\hline Argentina & 13,830 & $5.58 \%$ & 12,015 & $5.25 \%$ & 1,815 & $9.69 \%$ \\
\hline Bolivia & 2,420 & $0.98 \%$ & 2,270 & $0.99 \%$ & 145 & $0.77 \%$ \\
\hline Brazil & 13,455 & $5.43 \%$ & 11,700 & $5.11 \%$ & 1,750 & $9.34 \%$ \\
\hline Chile & 25,210 & $10.18 \%$ & 24,495 & $10.70 \%$ & 715 & $3.82 \%$ \\
\hline Colombia & 18,115 & $7.31 \%$ & 15,500 & $6.77 \%$ & 2,615 & $13.96 \%$ \\
\hline Ecuador & 11,370 & $4.59 \%$ & 10,905 & $4.76 \%$ & 465 & $2.48 \%$ \\
\hline Paraguay & 5,020 & $2.03 \%$ & 4,960 & $2.17 \%$ & 60 & $0.32 \%$ \\
\hline Peru & 18,105 & $7.31 \%$ & 17,120 & $7.48 \%$ & 985 & $5.26 \%$ \\
\hline Uruguay & 6,300 & $2.54 \%$ & 6,095 & $2.66 \%$ & 210 & $1.12 \%$ \\
\hline Venezuela & 8,035 & $3.24 \%$ & 7,055 & $3.08 \%$ & 985 & $5.26 \%$ \\
\hline $\begin{array}{l}\text { Total- Selected L.A. and } \\
\text { Caribbean Countries }\end{array}$ & 247,690 & $100 \%$ & 228,980 & $100 \%$ & 18,735 & $100 \%$ \\
\hline $\begin{array}{l}\text { LAC countries as \% of } \\
\text { all countries }\end{array}$ & $4.39 \%$ & & $4.20 \%$ & & $9.43 \%$ & \\
\hline
\end{tabular}

Source: Elaborated based on data from the 2001 Census of Canada, Cat. No. 97F0009XCB2001002 (Statistics Canada 2003). 


\begin{tabular}{|c|c|c|c|c|c|c|c|c|c|}
\hline \multicolumn{10}{|c|}{ Table 2} \\
\hline \multicolumn{10}{|c|}{ Migration Profile of Respondents by Country of Origin } \\
\hline & & & & & & & & & \\
\hline & & Colombia & Costa Rica & Ecuador & El Salvador & Guatemala & Mexico & & tal \\
\hline & & & & & & & & $\mathbf{N}$ & $\%$ \\
\hline \multirow{4}{*}{ Year of Arrival } & Before 1990 & 0 & 0 & 2 & 1 & 1 & 1 & 5 & $12.50 \%$ \\
\hline & $1991-2000$ & 2 & 0 & 2 & 4 & 3 & 3 & 14 & $35.00 \%$ \\
\hline & After 2000 & 8 & 6 & 2 & 2 & 1 & 2 & 21 & $53.00 \%$ \\
\hline & Total & 10 & 6 & 6 & 7 & 5 & 6 & 40 & $100 \%$ \\
\hline \multirow{7}{*}{$\begin{array}{c}\text { Legal Status Upon } \\
\text { Arrival }\end{array}$} & Refugee Programme & 7 & 3 & 1 & 3 & 1 & 0 & 15 & $38.00 \%$ \\
\hline & Landed Immigrant & 0 & 0 & 3 & 4 & 1 & 0 & 8 & $20.00 \%$ \\
\hline & Family Sponsorship & 1 & 0 & 1 & 0 & 2 & 0 & 4 & $20.00 \%$ \\
\hline & Tourist Visa & 2 & 3 & 1 & 0 & 0 & 5 & 11 & $28.00 \%$ \\
\hline & Student Visa & 0 & 0 & 0 & 0 & 0 & 1 & 1 & $3.00 \%$ \\
\hline & Ministerial Permit & 0 & 0 & 0 & 0 & 1 & 0 & 1 & $3.00 \%$ \\
\hline & Total & 10 & 6 & 6 & 7 & 5 & 6 & 40 & $100 \%$ \\
\hline \multirow{3}{*}{$\begin{array}{c}\text { Contacts in } \\
\text { Canada before } \\
\text { Migration }\end{array}$} & Yes & 5 & 3 & 2 & 0 & 0 & 3 & 13 & $33.00 \%$ \\
\hline & No & 5 & 3 & 4 & 7 & 5 & 3 & 27 & $68.00 \%$ \\
\hline & Total & 10 & 6 & 6 & 7 & 5 & 6 & 40 & $100 \%$ \\
\hline \multirow{6}{*}{$\begin{array}{l}\text { Length of } \\
\text { Separation from } \\
\text { Children }\end{array}$} & 2-6 Months & 1 & 0 & 0 & 0 & 0 & 0 & 1 & $3.00 \%$ \\
\hline & 7-12 Months & 5 & 3 & 1 & 2 & 0 & 1 & 12 & $30.00 \%$ \\
\hline & 13-25 Months & 3 & 2 & 3 & 0 & 0 & 2 & 10 & $25.00 \%$ \\
\hline & 3-5 Years & 1 & 1 & 1 & 3 & 4 & 3 & 13 & $33.00 \%$ \\
\hline & 6-8 Years & 0 & 0 & 1 & 2 & 1 & 0 & 4 & $10.00 \%$ \\
\hline & Total & 10 & 6 & 6 & 7 & 5 & 6 & 40 & $100 \%$ \\
\hline \multirow{3}{*}{$\begin{array}{l}\text { Mother-Child } \\
\text { Reunification }\end{array}$} & Yes & 3 & 2 & 3 & 6 & 3 & 3 & 20 & 50 \\
\hline & No & 7 & 4 & 3 & 1 & 2 & 3 & 20 & 50 \\
\hline & Total & 10 & 6 & 6 & 7 & 5 & 6 & 40 & $100 \%$ \\
\hline
\end{tabular}

